\title{
Masinloc, Zambales: Augustinian Recollect Mission (1607-1902)
}

\author{
Emmanuel Luis A. Romanillos \\ Recoletos School of Theology, Quezon City, Philippines \\ elaromanillos@gmail.com
}

\begin{abstract}
Zambales carved a unique niche in Augustinian Recollect's mission history. Recollects evangelized Mariveles, then part of Zambales, where their protomartyr Miguel de la Madre de Dios met his death. Rodrigo de San Miguel later set up five towns. In 1607, Andrés del Espíritu Santo founded Masinloc and then proceeded to create Casborran [Alaminos], Bolinao, Balincaguin [Mabini] and Agno in Pangasinan. Blessed Francisco de Jesús resided there before his 1632 martyrdom in Nagasaki. We recall the successful defense of Masinloc in 1649 against 600 Moro pirates by the natives headed by Father Francisco de San José. Its parish priest José Aranguren became Manila archbishop in 1845. In the wake of the Revolution, the returning Agustín Pérez was welcomed by his parishioners. He restored the Catholic worship and urged Aglipayans to return to the fold. In 1902, Father Pérez left due to a conflict with its anti-friar mayor. Thus, it ended its Recollect history. But the legacy of Christian faith lives on. The parish church of 1745 is a witness to the zealous Recollect evangelization and the people's steadfast Catholic faith.
\end{abstract}

Keywords: Augustinian Recollects, Church History, Mission, Masinloc, Zambales

Date Submitted: July 24, 2019

Date Revised: December 2, 2019

Date Accepted: December 29, 2019

\section{Beginnings of Masinloc Mission}

The Zambales of the Spanish colonial years comprised parts of Pangasinan and Bataan. Dominican and Augustinian missionaries initially tried to evangelize its vast regions. The attempts to spread the Gospel of Christ by the pioneering missionaries were rather sporadic and occasional. There was no authentic evangelization program for those regions. In 1591, an Augustinian missionary was slain by the inhabitants. 
Not long after, the first religious missionaries abandoned the area, citing the following reasons: "unhealthy clime, the natives' inordinate attachment to their traditions, and the courage and determination with which they defended such traditions." ${ }^{1}$

The fierce and bellicose character of the natives and the rugged terrain did not scare the Augustinian Recollect missionaries at all. Instead, the indomitable people and hostile land stirred up their zeal. The Recollects were pleased to accept the invitation of the encomendero Hernando de Avalos. The only friars in 1606 who could speak Tagalog were Fray Miguel Bombau de la Madre de Dios, Fray Pedro Vedoya de San José, and Fray Francisco de Santa Mónica, a religious brother. Fray Pedro and Fray Francisco had joined the Augustinian Recollection in Manila. So, the three missionaries journeyed to Zambales.

\section{Fray Miguel de la Madre de Dios, Augustinian Recollect protomartyr}

The hard work and activity of the first missionaries were astonishing. Of this, Augustinian Recollect Historian Father Angel Martínez Cuesta says: "Unmindful neither of the inhospitable terrain nor of the scarcity of food nor the vaunted ferocity and bellicose nature of the Zambales, the unfazed missionaries crossed rivers and creeks and climbed mountains and hills. They reduced the widely dispersed natives to impart to them the rudiments of the Christian faith more effectively and to prevent endless skirmishes."2

In early 1607 the pioneers reached Mariveles [now part of Bataan] and started spreading the Good News of Christ's saving mission. Fray Miguel de la Madre de Dios ${ }^{3}$ Spoke of Christian doctrines when the natives turned hostile and stoned the preacher, wounding him fatally. His was the first Recollect martyr's blood that would flow profusely through the decades in the missions of Zambales and Bataan.

Impelled by apostolic zeal and suffering all kinds of unimaginable deprivations and tribulations, more missionaries followed his footsteps. They sought the natives who lived in isolation in the wilderness of Zambales. Extreme hunger and the rigors of the clime soon put an end to the missionaries' young lives. "Just reading the accounts of their ordeal," says the Recollect historian Father Licinio Ruiz, "can make the soul shiver, even as they proclaim the greatness of their spirit."

\section{Fray Rodrigo de San Miguel, Zambales and Bataan missionary}

A man of truly great and enterprising spirit, Fray Rodrigo de San Miguel (15841626) traveled along the coast of Zambales and of what is known as Bataan to bring souls

${ }^{1}$ Ángel Martínez Cuesta, Historia de los Agustinos Recoletosı, Madrid 1995, 374.

lbid., 374.

${ }^{3}$ An Augustinian friar of Zaragoza, Spain, Fray Miguel Bombau de la Madre de Dios later joined the Recollects and their first mission to the Philippines. He was preaching the Word of God to the Aetas of Zambales in 1607 when the furious natives hurled stones at him, causing his death a few days after in their convent in Bagumbayan, Manila. Though he did not perish on the spot, Fray Miguel has always been revered as the Order's protomartyr. Cf. Emmanuel Luis A. Romanillos, The Augustinian Recollects in the Philippines: Hagiography and History (Quezon City) 2001, 120. Cf. also Emmanuel Luis A. Romanillos, Augustinian Recollect Icons, in The Recoletos Observer, April-June 2005, vol. 6, no. 2, 18.

${ }^{4}$ Licinio RuIz, Sinopsis histórica de la Provincia de San Nicolás de Tolentino de las Islas Filipinas. Vol.I (Manila 1925) 21. 
to the Catholic fold. ${ }^{5}$ Fray Rodrigo retraced the steps of the first Recollect missionary to Mariveles, where Fray Miguel de la Madre de Dios shed his life for the Christian faith.

Indistinctly known in history books as Fray Rodrigo Aganduru Móriz, the intrepid missionary from Valladolid, Spain, arrived with the first mission in May 1606. Bataan and Zambales-where he founded the towns of Bagac, Morong, Mariveles, Cabcaben, and Subic - witnessed his initial apostolic endeavors. As vicar provincial, Fray Rodrigo dispatched missions to Palawan and northern Mindanao and canonically erected in 1621 the convents of Cebu and San Sebastian in Manila. Death overtook him in Guipúzcoa, Spain, before he could comply with the Holy See's wish to send him as apostolic delegate to Persia, where he had earlier spread the Word of God. His writings on Philippine and Japan's missionologies, Tagalog and Zambal grammar, cartography, ethnography, medicine, and religion, deservedly earn him a niche in Philippine Church history.

Fray Rodrigo de San Miguel set up the town and parish of Subic in 1607. From the account of this daring Recollect missionary, we learn that the people of Subic practiced an animistic religion. It was said they worshipped the spirits in the forests. One day Fray Rodrigo saw a fruit-bearing tree, heavily laden with ripe and yellow fruits. The tree referred to was called pajo [mango]. It was believed to cause instant death that would befall anyone who touched the fruits and consumed them. It was furthermore deemed a sacrilege and a great sin just to be in contact with the tree. But Fray Rodrigo, with one hand holding the Crucifix while praying the Ecce Lignum Crucis, a Good Friday invocation in the Adoration of the Cross rite. He cut down the pajo tree and ate its fruit, even as he preached the saving power of Christ Jesus. Nothing evil happened to Fray Rodrigo, and at once, everyone accepted his preaching and received God's Word. ${ }^{6}$ Since time immemorial, Saint James the Apostle has been the patron saint of Subic.

\section{Fray Andrés del Espíritu Santo, first parish priest of Masinloc}

A native of Valladolid, Spain, and member of the pioneering mission, Fray Andrés del Espíritu Santo (1585-1658?) ${ }^{7}$ Founded the convent of Cavite Puerto in 1616. He was superior of the Recollects in the Philippines for a total of twelve years either as vicar provincial or as prior provincial, deftly guiding the young province in its decisive years of challenges and new missionary horizons. After the 11-month journey from Spain by way of Mexico, he reached Manila at the helm of the fifth mission with twenty-three members in 1622 that included the future martyrs-Blessed Melchor de San Agustín and Blessed Vicente de San Antonio. Historians owe it to Fray Andrés del Espíritu Santo for having chronicled the early Augustinian Recollect convents, churches, holy images, missions, brief biographies of religious and missionary arrivals in our

${ }^{5}$ RuIz, Sinopsisl, 21; Romanillos, Augustinian Recollect Icons, in The Recoletos Observer, April-June 2005, vol. 6, no. 2, 17.

${ }^{6}$ Patricio Marcellán, La Provincia de San Nicolás de Tolentino de los Agustinos Descalzos de la Congregación de España e Indias (Manila 1879) 50-51.

${ }^{7}$ Francisco SÁdABA, Catálogo de los Religiosos Agustinos Recoletos de la Provincia de San Nicolás de Tolentino de Filipinas Desde el año 1606, en que llegó la primera misión a Manila, hasta nuestros días (Madrid 1906) 42-43. Cf. also Romaniltos, Augustinian Recollect Icons, in The Recoletos Observer, vol. 6, no. 3 (JulySeptember 2005) 23-24. 
country (1605-1645). ${ }^{8}$

From Manila, Fray Andrés del Espíritu Santo traveled to the north of Luzon by sea and reached Masinloc in 1607 with Fray Jerónimo de Cristo.9 Fray Andrés is deemed as the founder of Masinloc and builder of the first church of Almighty God in the new pueblo. The two missionaries spent months in the area, nourishing their frail bodies solely with root crops and vegetables.

In 1609, Fray Andrés and Fray Jerónimo proceeded further north of Zambales and founded the town of San José de Casborran [actual Alaminos City] and Bolinao which are now part of Pangasinan. In 1610, they resettled the natives and founded the new towns of Balincaguin [present-day Mabini] and Agno.

\section{Masinloc, center of evangelization}

In the course of time, Masinloc would become the center of Augustinian Recollect evangelization for northern Zambales, which stretched from Iba to Anda. Customarily, four or more religious missionaries resided in Masinloc.10 Thus, according to a Recollect chronicler, Masinloc possessed "la mejoriglesia y el mejorconvento," the best church and the best convent in the whole province of Zambales.11 The pueblo continued its purpose as a mission springboard, which had commenced at the outset of the evangelization of Zambales in 1607.

\section{Toponym}

The toponym of "Masinloc," according to the Recollect Father Vicente Pascual's 1891 brief account on the history and events of the pueblo, can be traced to " $m a$ " [which means, "place teeming with"] and "sinloc," "una planta que crece hasta metro y medio de tallodelgado y hojas estrechas y largas." Translated into English, the phrase means sinloc is a "plant that grows up to a meter and a half tall, with a thin stalk and narrow and long leaves." About a kilometer or two northeast of the present site of Masinloc, continues from Father Vicente Pascual's historical account, there is a place named "masinlocan" or a "place where the sinloc plant thrives in abundance." The people, especially the llocanos, presently term the plant arono.

Sinlocis not a tree, as conjectured by people nowadays. Unfortunately, there exists an article on Masinloc toponym that conjectures the loss of its meaning: "The name Masinloc came from majinloc, meaning a place where the jinloc grows in abundance. Whether a tree, shrub, vine, or what-not, the identity of the jinloc seems now lost to us, but there still exists a sitio near the town on the river bank, which is called

${ }^{8}$ Fray Andrés is the author of Relación de la fundación y progresos de esta santa Provincia de San Nicolás de Tolentino, in Boletín de la Provincia de San Nicolás de Tolentino de Filipinas [BPSN] 55 (1965) 66-179.

${ }^{9} \mathrm{Cf}$. SÁDABA, 36. An Augustinian since 1593, Fray Jerónimo joined the Recollects in Zaragoza, Spain. He was named prior of the first Recollect convent of San Juan de Bagumbayan and vicar provincial in 1608-1609. He was in this last position when he saw the need for missionaries in Zambales. He joined Fray Andrés in Masinloc and got seriously ill. He passed away in 1607 in Bolinao, which was then part of Zambales, now under Pangasinan.

${ }^{10}$ Vicente PASCUAL, Breve reseña histórica de la fundación y vicisitudes por que ha pasado esta parroquia de Masinloc, Archivo Histórico Provincial de la Provincia de San Nicolás de Tolentino, Marcilla, Navarre, Spain, Folder 4, 8v-9r.

${ }^{11}$ lbid., $8 \mathrm{v}$. 
Cajinlocaqan, that is full of jinloc."12

\section{Clime and agricultural products}

The climate of Masinloc, as reported by an Augustinian Recollect historian, was healthful.13 The land produced palay in abundance. Medicinal plants further abounded in the area. Potable water was available everywhere. Two rivers named Baliti and Vavandui that flowed from east to west irrigated the vast fertile land. Various kinds of trees grew in the forests, and they constituted an endless source of wood for the construction of houses and buildings.

In Masinloc Fray Andrés del Espíritu Santo built the first house of God, which was ordinarily made of light materials. The first church did not last long. The present church was constructed in the 18th-19th century by the Augustinian Recollect missionaries. It is the best example of a colonial church complex in the province, although it was heavily hit by a strong earthquake that struck at dawn in December 1999.

\section{Triumphs and Travails of Augustinian Recollect Evangelization}

\section{Aetas attack new Christian communities}

An indomitable group of Aetas or Negritos opposed the evangelization effort of Fray Andrés del Espíritu Santo and his coadjutor. They sporadically but ferociously attacked the areas that sprawled between Zambales and Pangasinan, playing havoc on the new Christian settlements and farms, killing some converts in the process. These upland dwellers were dreaded because of their appalling, horrifying cruelty, beheading Christians, and committing all kinds of atrocities acts against them. Government soldiers were dispatched to subdue the pillaging Aetas, but the headhunting tribe rushed to their mountain hideouts and vanished in the wilderness. ${ }^{14}$

A fort was finally built in Playa Honda to protect the lives and properties of the new Christian converts. Hence, the Aeta attacks were contained, and the missionary activity and civilization work of the Recollects were consolidated. Fray Andrés was assigned as chaplain of the fort and missionary of the area. The Recollect pastor further maintained the peace and order between the natives and Spaniards. The military garrison helped maintained the harmony between them. A new town soon surged forth from this community and was called Iba, the present capital of Zambales province.

In 1760, Governor-General Manuel de León ordered the construction of a stronger fort and permanently assigned twenty-three soldiers to its garrison.

Blessed Francisco de Jesús.

The Spanish Blessed Francisco de Jesús (1590-1632), a native of Villamediana, Palencia, joined the Recollect Congregation in 1615. The Recollect mission, which he joined, left Cádiz in May 1619 and reached Vera Cruz, Mexico, in August 1619. They proceeded to Acapulco, and from there, they traveled to Manila, where they debarked in August 1620. Two typhoons buffeted their galleon named San Nicolás. A fire hit the stern of the ship, but the missionaries landed safely in Manila. Father Francisco learned

\footnotetext{
${ }^{12} \mathrm{http}: / /$ www.zambales.gov.ph/

${ }^{13}$ SÁDABA. 51.

${ }^{14}$ RUIz, Sinopsis, 23.
} 
Tagalog in Manila and Cavite.

It was towards the end of September 1620 when Father Francisco de Jesús was assigned to Masinloc. ${ }^{15}$ He spent three months in this mission (October-December 1620). He was then sent to Bolinao in the north, where he stayed until 22 September 1622.

In early 1623, Fray Andrés del Espíritu Santo as the major superior in the Philippines appointed Fray Francisco as vicar provincial with Fray Vicente de San Antonio in the Augustinian Recollect mission to Japan. With eight other missionaries, the two Recollects reached Japan in June 1624. They risked their lives and preached the Gospel in Nagasaki and Yokinaura until Japanese authorities arrested them in 1629. After years of imprisonment and tortures, they suffered martyrdom on 3 September $1632 .{ }^{16}$

\section{Fray Francisco de San José (1632-1668)}

Fray Francisco de San José came to the Philippines in $1645 .{ }^{17}$ He was elected provincial in 1653 and 1659. As a provincial councilor, he was in Masinloc in 1649 when the Moros from Jolo and Borneo organized raiding expeditions against the towns in Luzon, where they committed atrocities no end. Six Moro caracoas had landed at the shore of Masinloc. Over six hundred Moro fighters had started disembarking. A great majority of the residents - scared out of their wits-had hastily scampered for safety in the neighboring mountain fastness.

Fray Francisco de San José led the Zambaleños in the brave defense of their town. The people put up a great fight and successfully repelled the Moro invading forces, causing human casualties among them. The survivors fled to an adjacent islet named Pulô San Salvador to fight another day. The next day Father Francisco led a huge number of emboldened Zambaleños who attacked the hideout on the island and finished off the unwary Moros. The dauntless Masinloc fighters eventually captured the caracoas laden with war material and proclaimed complete victory over the Moro pirates.

In 1668 Fray Francisco de San José, who was assigned to Romblon as a parish priest, successfully repulsed the invading Moro invading forces through artillery fire. At the height of the fierce battle, the missionary was seriously wounded and died very shortly after.

\section{Fray Cristóbal de Santa Mónica (?-1693)}

Fray Cristóbal de Santa Mónica was prior of Masinloc $(1641,1647,1654)$ and Mariveles (1644). ${ }^{18}$ As prior provincial in 1656 and 1668, he gave a major impetus for the resettlement of the inhabitants of Zambales province and worked hard for the prosperity of its mission posts and towns. Previously, there were only three strategic residences: Mariveles, Masinloc, and Bolinao. Sigayan, present-day Santa Cruz, had been suppressed in 1661. From the three central residences, other towns and barrios were periodically visited by the Recollects who sojourned there for some time according to the spiritual needs of the parishioners. In 1647, Fray Cristóbal increased the number of missionaries and mission stations. He set up two more residences: one in Peinaben

\footnotetext{
${ }^{15}$ Manuel CARCELLER, Historia general de la Orden de Agustinos Recoletos, XII, (Madrid 1974) 32.

${ }^{16}$ SADABA, 50-54.

${ }^{17}$ SADABA, 92-93.

${ }^{18}$ SADABA, 89-90.
} 
(Playa Honda or Iba) and another in Bagac. The residence of Bagac was later transferred to Morong.

\section{Four towns were carved out of Masinloc ${ }^{19}$}

The first visita of Masinloc to separate and become an independent town and parish was Iba. Spelt as Yba during the Spanish Regime and known in the past as Peinaben or Playa Honda, Iba was founded in 1611, as recounted by our Recollect chronicler Father Vicente Pascual. But another Recollect historian Father Fide del Blas contends in his book La Labor evangélica de los padres recoletosen las Islas Filipinas that Iba was founded only 1681.20 The foundation of the future capital of Zambales is attributed to both Father Rodrigo de San Miguel and Father Andrés del Espíritu Santo.

The second oldest visita of Sigayán, erstwhile name of actual Santa Cruz, was created as an independent pueblo from Masinloc, its town and parish matrix, in 1612. It was Father Alonso de San Agustín who, through personal initiative labored to erect the present-day town of Santa Cruz. Our chronicler Father Vicente Pascual recounts pertinent information on the name of Sigayán. According to the third entry of the First Book of Baptisms in the parish archives of Masinloc, a Dominican friar named Fray Bartolomé de Estrada had administered on 8 April 1662 the sacrament of Baptism to three individuals in the barrio of Sigayán, which belonged to the parish of San Andrés of Masinloc. The signature of the Recollect parish priest Father Juan de San Diego, who affixed it on 3 June of the same year of 1662, followed that of Fray Bartolomé de Estrada.

The Christian natives of the town matrices of Masinloc and Iba resettled in Palauig, which became a new town. Father Fidel de Blas writes that Palauig was founded as a parish in 1873.21

San Vicente was the old name of Candelaria. As an independent town, Candelaria was separated from its town matrix Masinloc on 21 April 1871. A royal order was issued at the Spanish capital of Madrid on 21 June 1892, declaring the new parish of Candelaria independent from the parish matrix of San Andrés of Masinloc. We do not know the reason why the separation of Candelaria from its parish matrix was again decreed in early 1893.

\section{San Andrés Church}

Father Agustín Pérez de la Inmaculada Concepción was tasked by the Recollect prior provincial to write down the remarkable annals in the history of Masinloc in a Libro de cosas notables. ${ }^{22}$ This could have been a very vital document for our investigative effort, had it survived to these days. Unfortunately, what could have constituted an important document for our historical narrative is seemingly lost to posterity.

In the parishes of the Visayas, the Recollect parish curates had ample time

\footnotetext{
${ }^{19}$ Vicente PASCUAL,Breve reseña histórica de la fundación y vicisitudes por que ha pasado esta parroquia de Masinloc, Archivo Histórico Provincial de la Provincia de San Nicolás de Tolentino, Marcilla, Navarre, Spain, Folder 4, 14r.

${ }^{20}$ Fidel DE BLAS, Labor evangélica de los padres recoletos en las Islas Filipinas (Zaragoza 1910) 16.

${ }^{21} \mathrm{lbid}$.

${ }^{22}$ Vicente PASCUAL, Breve reseña histórica de la fundación y vicisitudes por que ha pasado esta parroquia de Masinloc, Archivo Histórico Provincial de la Provincia de San Nicolás de Tolentino, Marcilla, Navarre, Spain, Legajo 50, Folder 4, 14r.
} 
to copy the original Cosas notables of more than twenty parishes under their spiritual jurisdiction manually. The original manuscripts were left behind in the parochial archives with other canonical books when the Recollect priests were advised to abandon their parishes and leave for Manila in November 1898. The copies of the Cosas notables are now kept in the Archivo Historico Provincial de la Provincia de San Nicolás de Tolentino (Provincial Historical Archive of the Province of Saint Nicholas of Tolentino), in Marcilla, Navarra, Spain. Digitized copies of the Cosas notables are available to researchers at Archivo Recoleto of Bulwagang Recoletos in Quezon City.

It was providential, though, that a diocesan parish priest of Masinloc had the foresight, and for future researchers, he had the two old baptismal books copied manually. ${ }^{23}$ The secular priest Father Gabriel José Martínez del Burgo, who was a parish priest in 1785-1789, saw the lamentable condition of the parochial books whose first baptismal entry was in October 1661. From these books, Father Vicente Pascual was able to reconstruct in 1891 the list of parish priests from 1661 to 1891 . Without Father Martínez del Burgo's good sense, the names of the parish curates could have vanished to oblivion forever.

Father Agustín Pérez, who authored the Cosas notables of Masinloc, was at the helm of the parish for a total of sixteen years: 1877-1891, 1895-1898. His successor Father Vicente Pascual, parish priest from 1891-1895 and author of our highly useful Breve reseñahistórica de la fundación y vicisitudes por que ha pasadoestaparroquia de Masinloc (Brief historical account of the foundation and events through which this parish of Masinloc has passed), mentions the existence of Father Agustín'sLibro de Cosas notables de Masinloc. He further tells us that Father Agustín had done some extensive research on the history of the stone church of San Andrés, relying mostly on oral tradition. He had interviewed the old folks of the town for his Cosasnotables.

\section{The strong church edifice}

According to the Breve reseña de la fundacion y vicisitudes de Masinloc (Brief historical account of the foundation and events of Masinloc), the construction of the present church of Masinloc was begun in 1745. As recounted in 1891 in the now-extinct Libro de cosas notables, by Father Agustín Pérez, who administered the San Andrés parish for fourteen years, tradition has it that the Augustinian Recollect missionaries constructed the stone church in 1745 . We do not have an inkling as to the date the church edifice was finished. The identity of the Recollect parish is not available because the second baptismal book of the parish during the Spanish period ended in February 1726. Blame it on the anay, bokbok, typhoon, heavy downpour, earthquake, bad quality of rice paper, or any paper, or simply the wear and tear of the centuries.

But when the diocesan priest Bachiller Don Gabriel José Martínez took over the parish administration in January 1785 from the last Recollect parish priest Father Manuel de Jesús y María, the second baptismal book of the March 1726-December 1784 was no longer available. The 58-year silence of the documentary sources is a heavy burden for the researcher or historian.

The unreliable oral history gathered in 1891 further says the stone church was destroyed by a powerful earthquake that leveled it to the ground in 1798, and

\footnotetext{
${ }^{23}$ Ibid., $11 \mathrm{v}$.
} 
this year was likewise the year it was finished! Father Vicente Pascual, however, puts this twin assertion in doubt. From his research, no research took place in 1798 . There were earthquakes in 1754 and 1766 . Which of these two tremors demolished the stone church of Masinloc? We can never tell. But we are assured that no earthquake occurred in 1798.

From a highly reliable source, we learn that the diocesan priest Bachiller Don Miguel Gregorio Jiménez, was the only parish administrator who worked so much for the restoration of the old church. He took over the parochial management on 12 June 1825. The rest of the parish priests were only on an interim basis, and they stayed in Masinloc on an average period of one to two years. There was not enough time to do restoration work on the damaged church.

The doorway to the choir loft is carved and polychromed; it is the unique feature of the San Andrés Church after the facade. ${ }^{24}$

\section{Description of the church edifice after the Revolution}

Father Agustín Pérez returned to Masinloc in December 1901 and stayed for only four months. ${ }^{25}$ According to his account, the church edifice remained the same as before during his time. No serious damage had been inflicted on the church of San Andrés by the revolutionaries. They had mercilessly burned down a great number of the best houses and buildings in Masinloc. They inexplicably spared the church and the convent.

Father Agustín Pérez noted that the small door of the marble tabernacle had been forced open and destroyed. The stone church had been left on its own for three and a half years. Apparently, no Aglipayan minister took possession of the divine temple during the dearth of Catholic priests. The years of abandon and absence of maintenance had taken a heavy toll on some parts of the church. The wooden floor had some portions already rotten and badly needed immediate replacement. Two windows were broken. Broken too was the pedestal with a cross. Coping of the façade had fallen to the ground. This masonry piece was carried inside the church for safekeeping because it could not be returned to its place in the church façade.

The returning Recollect priest further reported that, among the church vestments and vessels, he found the silver ceremonial cross and the ciriales (mounted candle-holders) for religious processions, the silver incensario (censer), and the bronze acetre(small pail) with its silver hisopo (holy water sprinkler). Almost all the casullas (chasubles) used before the revolutionary turmoil were still in the cabinets. However, there was but one alba (alb, the long white tunic). Only two manteles (altar covers), three corporals, and some purificators were usable.

${ }^{24}$ E. L. A. Romanillos, Augustinian Recollect Icons, in The Recoletos Observer, October-December 2006, vol. 6, no. 4, 27.

${ }^{25} \mathrm{AHPN}$, Agustín PÉREZ. Relación del viaje del que suscribe a Masinloc (Zambales) y de lo acaecido durante mi permanencia de cuatro años en el mismo pueblo. Folder 2, 18r. 


\section{Father José Aranguren OAR, Church Builder}

\section{Religious life}

The future parish priest of Masinloc and archbishop of Manila, José Aranguren, was born in Barasoain, Navarre, Spain, on 16 February 1801. ${ }^{26}$ José's parents, Bernardo Aranguren and Nicolasa Leoz, belonged to a well-off and righteous family. He joined the military service and fought with the famous Mantilla Cavalry. He later realized that "his God-given talents and good character" were not for waging war but winning souls for the Almighty. He studied Latin grammar and went to the University of Zaragoza to take up Law.

Before long, he embraced the lifestyle of the Augustinian Recollects. On 7 December 1825, he entered the newly-opened seminary college of Alfaro in La Rioja, the first formation house of the Province of Saint Nicholas of Tolentino in Spain since 1621. A year after, on 8 December 1826, he professed the three evangelical counsels of poverty, chastity, and obedience. After his arrival in the Philippine, he taught theology to young Recollect aspirants in Intramuros. Eager to practice his pastoral ministry, Aranguren was sent to Taguig to learn the rudiments of Tagalog. Capas, Tarlac, was his first apostolic ministry. He moved shortly after to Masinloc as its parish priest in 1836-1843. The new parish priest arrived in Masinloc on 13 April 1836. He then took possession of his curacy on the $20^{\text {th }}$ of the same month. The Cosas notables of the parish further noted that it was on 10 May 1836 when he finally received canonical collation. ${ }^{27}$

Aranguren was elected by the provincial chapter as prior provincial for the 1843-1846 triennium. However, he had to cut short his term because in 1845, he was appointed to the metropolitan see of Manila by Pope Gregory XVI. During the sede vacante of the Diocese of Cebu, Father Aranguren's name was among the shortlist of candidates.

\section{A religious of exemplary character and disposition}

Archbishop Aranguren was a kind-hearted man, known too for his tact and prudence as well as for the spirit of poverty and self-denial. He enjoyed the reputation of a learned man in the Sacred Letters and Canon Law, "endowed with an exemplary way of life and praiseworthy character." ${ }^{28} \mathrm{He}$ always concerned himself with helping the marginalized sectors of Manila society. Most of all, he was a staunch defender of the rights of the diocesan priests. He fought for the retention of parishes of diocesan priests, which were to be handed over to the religious orders. For the care of ill people in hospitals, the archbishop facilitated the coming of the Sisters of Charity to the Philippines. In 1851, he completely supported the establishment of Banco Español-Filipino, which in due time, became the Bank of the Philippine Islands. Archbishop Aranguren died in Manila on 18 April 1861.

\footnotetext{
${ }^{26}$ SÁDABA, 403-406.

${ }^{27}$ SÁDABA, p. 404, affirms it was on 10 March.

${ }^{28}$ Manuel CARCELLER, Historia general de la Orden de Agustinos Recoletos XI, Madrid 1967, 145.
} 


\section{The Gauntlet of the Philippine Revolution}

The bloody Revolution began in Zambales only in March $1898 .^{29}$ On account of the dangerous situation in the towns which had risen in arms against the Spanish Regime, the Recollects left their parishes and traveled to Subic. In May, Father Pablo Calvillo of Castillejos joined Father Buenaventura Iturri of San Marcelino and Father Luis Cabello in their journey to Subic. Subic, whose parish priest was served by Father Manuel Jimenez, was at that time considered as the safest point in the entire province. It was very easy to embark on a boat from Subic to the safe haven of Manila. They would be out of harm's way once they were in Subic. We remember that it was the port of the Spanish Navy or what was left of it after the Battle of Manila Bay against the American warships.

The four Recollects-ever faithful to their priestly vocation and religious commitment-spent one month in Subic doing what was expected of them: preaching and confessing the friendly people of Subic in all peace and tranquility. But the revolutionary storm was fast approaching. Filipino revolutionaries were nearing Olongapo. The Spanish citizens decided to transfer to an islet fronting Subic, where they eventually suffered scarcity of food and concomitant hunger. American warships fired against the refugees in the islet without causing anything casualty, but scaring the wits out of them. They were told by disembarking Americans to move to Olongapo, where the revolutionaries arrested them. Father Francisco Moreno, the church builder of San Narciso, joined them in captivity.

\section{Via Crucis, a la Recoletana}

Another version of the foregoing event says that Fathers Pablo Calvillo, Luis Cabello of Olongapo, Francisco Moreno, Fernando Hernández of Botolan, Agustín Pérez of Masinloc, Valentín Borobia of Palauig, and Hipólito Navascués of Candelaria escaped to the safety of Subic. They ministered to the spiritual needs of the people. On 29 June 1898, the seven Recollects were all arrested by the revolutionary troops of General Gregorio, based in San Antonio. Thereafter they were dispersed throughout Zambales. Father Francisco Moreno was taken to Iba and was subjected to hard labor. Father Luis Cabello and Father Pablo Calvillo were tied together and taken as prisoners to Castillejos. When the parishioners saw their parish priest-who had served their sacramental needs for twenty-nine years, they welcomed him joyfully and warmly, and gladly offered him food and drinks. This was for sure to the consternation of the revolutionary guards.

In the ensuing weeks and months, they trekked in pairs or groups to various places under close guard to La Paz, Capas, Tarlac, Pangasinan, Nueva Vizcaya, Ilocos, and even Cagayan. The situation of the captives in the territory under General Makabulos for three months was much better for the religious prisoners. They enjoyed relative freedom: they complied with religious duties, learned English from a Dominican friar. The harsh and exhaustive pilgrimage was assuaged by the generosity, hospitality, and warmth shown by the simple people along the way. Far from the clutches of anti-friar

${ }^{29}$ Licinio RuIz, Sinopsisıl, 405. We faithfully follow the narration of the Recollect side of the Philippine Revolution. The account was culled from the various reports made by the Recollects who had been eyewitnesses of the horrors and humiliations they suffered during those tumultuous times of our history.

Volume 2 Number 2 July-December 2019 
Katipuneros, most of the prisoners regained their freedom in December 1899-after one and a half years of captivity.

\section{The Aftermath of the Revolution}

\section{Back to Zambales}

Father HipólitoNavascués and Father Fernando Hernández, both ex-prisoners of the Katipuneros, returned just the same to Zambales in 1901. They were told to assess the religious situation of Zambales and administer the priest-less parishes. Some of these curacies at that time had fallen into the hands of the ministers and members of the Iglesia Filipina Independiente [Philippine Independent Church or Aglipayan Church]. The Recollect missionary work was not so easy then. There were but six diocesan priests in the whole province. The Roman Catholics were over a hundred thousand before the Revolution, and twenty-four Recollects were in Zambales to minister to their spiritual and sacramental needs.

During and after the years of the Revolution, very few Recollect priests and brothers remained in the Philippines. A great number of these missionaries had traveled back to the overcrowded convents of Spain. In the coming years, still more friars went to the old convents and parishes as well as to newly opened mission territories in Central and South America.

The gauntlet of the Philippine Revolution came to pass. Father Agustín Pérez de la Concepción left the Recoletos convent of Intramuros. He was granted permission by his superiors and he traveled to Masinloc. ${ }^{30}$ It was on 3 December 1901 . He was with his confrere Father Alejandro Echazarra de la Concepción. The interim archbishop of Manila granted Father Agustín the faculties to take spiritual charge of Masinloc. He was also equipped with faculties to administer the sacraments in Masinloc, including that of holy matrimony, as well as in other Zambales towns where no priests were assigned.

On 6 December, upon orders of the American ship captain, they were asked to debark at the provincial capital of Iba against their will, although they paid their fare up to the shore of Masinloc. The returning missionaries were promised that from Iba, they would be taken to their destination. Their confidence was boosted when an American officer ordered the soldiers to carry their baggage to a hut at the shore for safekeeping. Father Pérez and Father Echazarra then rode a four-wheel carriage and proceeded to the residence of the presidente municipal.

\section{A drunk hurled invective at the priests}

Two hours afterward, without permission, a drunk entered the compound of the mayor's residence and started yelling at the top of his voice: "We don't want friars! Away with friars!" The owner of the house descended and tried to drive him away and told him to shut up. He stood his ground and told the mayor: "Yes, I will shut up but send away the friars!" The drunk threw up there and then and the spirit of the local wine that wielded power over him and endowed him with strength and audacity deserted him at once. Sober and in his right wits, the troublemaker withdrew. The two

${ }^{30} \mathrm{AHPN}$, Agustín PÉREZ, Relación del viaje del que suscribe a Masinloc (Zambales) y delo acaecido durante mi permanencia de cuatro años en el mismo pueblo, Folder 2, 16r-20r. 
Recollect priests spent the rest of the day and night in peace. The next morning, they heard about a gravely ill woman who badly needed the sacraments of the Holy Mother Church. Undaunted by the few individuals who did not want their presence in Iba, the missionaries hied off to the ailing woman who sought the consolation of the sacrament of Penance.

\section{Town officials of Iba came for a visit}

The news of the return of the Recollect priests soon spread like wildfire. A commission of eight or ten people, "the most hostile to the religious," called on the municipal mayor at 10:00 am. They went up to the house and showed themselves before the mayor and the priests. They said they did not want friars and wanted to know if the Recollects had gone to Iba to exercise their pastoral ministry. The mayor permitted Father Pérez to speak, and this priest simply told the unfriendly group that he and Father Echazarra had intended to go up north, but they were told to disembark by the ship captain at Iba. As soon as they could acquire a couple of carts, they would proceed to their destination. The mayor told them the bridge connecting Iba to Palauig was non-existent. Thus, the Americans begged off from transporting them to Masinloc. The mayor granted the priests' request for two carts for their journey.

\section{Off to Palauig}

Thus, on 7 December, they traveled to Palauig. There the missionaries spent the night in the house of the former church fiscal. The next day was 8 December, a Sunday and feast of the Immaculate Conception. As there were no ornaments or paraphernalia needed for the celebration of the holy mass at Palauig, they decided to leave at dawn for Masinloc, where they could celebrate mass with more decency and decorum. They hired a small boat and reached Magalawag Island at midday. The impoverished residents readily prepared lunch for them: cooked rice, fish, and eggs. The priests wanted to pay for their meal, but the people adamantly refused to accept their money. They sailed to Masinloc and reached its shore between three and four in the afternoon of 8 December 1901.

\section{Father Agustín Pérez de la Concepción OAR}

Born in Marcilla, Navarre, Spain, on 13 October 1849, Father Agustín Pérez de la Inmaculada Concepción joined the Congregation of the Discalced Augustinians when he professed the three evangelical counsels of poverty, chastity, and obedience. ${ }^{31} \mathrm{His}$ religious profession was on 29 July 1868 . He joined the $64^{\text {th }}$ Recollect mission to Manila, where he arrived on 25 May 1897. The dimissory letter for his sacerdotal ordination was issued on 26 October 1872. He traveled to the Visayan city of Iloilo, where he was ordained as a priest by the Dominican bishop Mariano Cuartero at the cathedral church of Jaro.

On 17 June 1873, Father Agustín was then dispatched to San Felipe, Zambales, to learn the Zambal language. The historical account written by Father Vicente Pascual informs us that his twenty-seven-year-old confrere was installed as parish priest of

\footnotetext{
${ }^{31}$ SÁDABA, 562-563.
} 
Masinloc on 15 May 1877. ${ }^{32}$ When Father Agustín ended his first term as a parish priest when he was elected prior of their Convent at San Millán de la Cogolla, La Rioja, Spain. Father Vicente then took over his post on 15 March 1891.

At the end of the triennium, the provincial chapter of 1894 elected Father Agustín as prior to their convent and novitiate at Monteagudo, Navarre, Spain. Moreover, he resigned from his post shortly after and returned to Manila on 25 July 1895. He was appointed anew as parish priest of Masinloc until his capture by the revolutionaries in 1898. He regained his freedom in December 1899 and resided at San Sebastian Convent in Manila until he left for Spain in October 1905. He resided at the convent of his hometown Marcilla in Navarre, where the Recollect seminarians studied their theology. On 10 January 1915, at age 65, he returned to his Maker after receiving the last sacraments. ${ }^{33}$

\section{A very friendly welcome at Masinloc}

There was not a single soul at the town plaza of Masinloc to welcome Father Agustín Pérez and Father Alejandro Echazarra, for their coming was not expected after all. When some women and young children knew about missionaries' arrival, however, they rushed forth to meet them and kissed their hands with the utmost respect. The presidente municipal soon at once went to see the two Recollects and greeted them. He then expressed his wish to lodge them at his residence. As they headed for the house of the mayor who had a big family, another friendly resident invited them to stay at his own house with his small family. So, the two priests acceded to his request and sojourned temporarily at his residence.

The leaders of the community and other people then came to visit the priests there. The welcome was pleasant, as it was peaceful, and no untoward incident took place. From that first visit, the Recollects could not ascertain how the people felt about their Catholic faith nor for its ministers. They could not identify who was hostile to them or not.

\section{Pastoral exhortations}

Father Agustín exhorted the welcoming party to forget the bitter past. He told those who have joined the Agliplayan sect to return to the Catholic fold and form only one Christian community. The returning priest promised that his attitude toward them would be beyond reproach as he had been doing during the sixteen years when he was their parish priest. They never had, as they themselves had confessed to the Recollect priest, any complaint against him at all.

The next day 9 December 1901, a Recollect confrere Father Hipólito Navascués who was assigned to the neighboring town of Candelaria, arrived at Masinloc. The two compared notes on the status of their spiritual jurisdictions. Father Navascués told him about the parishes in northern Zambales. The good prospects for their continuing evangelization tasks in these areas must be observed. The Canderlaria missionary thus

${ }^{32}$ Vicente PASCUAL, Breve reseña histórica de la fundación y vicisitudes por que ha pasado esta parroquia de Masinloc, Archivo Histórico Provincial de la Provincia de San Nicolás de Tolentino, Marcilla, Navarra, Spain, Folder 4, 14r.

${ }^{33}$ Miguel AvelLANedA OAR, Continuación del Padre Sádaba, o segunda parte del 'Catálogo de los religiosos de la Orden de Agustinos Recoletos' (1906-1936) (Rome 1938) 384. 
took Father Echazarra with him to Infanta and left Father Agustín alone in Masinloc. Father Echazarra was to assist his confrere Father Fernando Hernández in Infanta.

\section{Father Agustín's initial observations}

At Masinloc, Father Agustín asked the presidente municipal for a house where he could fix his residence. The town executive told him of a vacant house between his own and that of the detachment commander of the American soldiers. The United States officer wielded command over sixty to seventy men. Most of these soldiers were black Americans.

On 12 December, Father Agustín moved to the nipa hut with a flooring whose wood had not yet been nailed together permanently. The floor was a little over one meter from the ground. A lot of holes dotted the roof. The parish priest agreed to pay three pesos and a half to the owner as his rent for the dilapidated nipa hut. It was one of the best shanties in town! Among them, of course, were houses of the mayor, the councilors, and the American military officer. The foreign soldiers seized the sturdy parochial convent, among other good houses, as their residences.

The Katipunan members had razed to the ground all the stone and wooden houses of the town. Consequently, in those turbulent moments of history, the people evacuated to the outskirts of Masinloc. The returning Spanish priest observed that houses were still being constructed in the outlying barrios. No houses had been built in the town proper. The population was estimated by Father Agustín to be the same as that of 1898: 2,700 residents.

\section{The moral and spiritual plight of the parishioners}

The Recollect pastor administered the sacraments when requested by the parishioners. He celebrated the holy mass at the most convenient time for them, even during holy days and festivities. He never ceased to preach the sacrament of penance. Not much fruit was gathered. The people had seen scandals and received wrong teachings since the start of the Revolution. These were easily deceived out of their ignorance and indolence, noted Father Agustín in his memoirs. He added that the people in the outlying barrios were receptive of the sacraments.

The missionary suspected that an unseen force had done everything to put obstacles to his evangelization endeavors. Someone was trying to make his sojourn in Masinloc next to impossible. He noted the strange conduct of the presidente municipal named Juliano Estella. The town executive was in his fifties, a bit older than the parish priest. The Recollect had not met him until two years before the outbreak of the Revolution. The presidente municipal had either fled or was exiled for seventeen years on account of some crime he had committed, according to what Father Agustín had heard. The Katipunan of Masinloc had designated Estella as presidente municipal. The victorious American forces reappointed him to the same position.

Mayor Estella had nothing personal against the priest initially. Nevertheless, on one occasion, the mayor sent him a letter threatening him with a fine after the solemnization of a marriage. Several times, the mayor attended the weekday masses but failed to go to church for mass on holy days and Sundays. Weddings already announced earlier never took place because of Mayor Estella's stiff opposition. "Young 
children," the missionary writes in the historical account of his sojourn at Masinloc, "to whom I ordinarily taught the Christian doctrine before, later on, kept themselves away from me."

\section{Conflict between the mayor and the parish priest}

The priest suspected that the provincial officials in Iba had exerted great influence on Mayor Estella. As events would show afterward, the mayor would meddle endlessly in purely church affairs. And he would thus display his dictatorial attitude in the process. This would happen during the Holy Week of 1902. The Recollect minister had announced to his parishioners that there would be no Eucharistic celebration in the morning of Good Friday. The mayor issued a public announcement to all and sundry that the people should go to church to pray the rosary on Holy Thursday and join the religious procession in the evening of Holy Thursday and Good Friday. Further revealing his crass ignorance on Church canons and liturgy, the mayor ordered the priest through the sacristan to celebrate mass in the morning of Good Friday! Father Agustín replied he could not accede to his command.

All told, a procession was held on Holy Thursday on mayor's order against the parish priest's wishes. The next day Good Friday, Mother Nature intervened: a heavy downpour impeded the procession. The parishioners instead prayed the rosary at church and went home afterward. The Paschal Vigil of Black Saturday took place without any untoward incident.

On Easter Sunday, a pompous and solemn mass was celebrated. Following his thanksgiving prayer, Father Agustín went out of the house of God. Lo and behold, all the members of the town council were waiting for him at the church portal. To his utter bewilderment, the town band was there too playing martial music. The Recollect priest was taken aback. He could not believe what he was seeing. Anyway, he played along. With the town mayor at his left side, he walked towards his humble residence. Such was the traditional practice under the Spanish Regime. But Masinloc was already under American Occupation.

The next Sunday was another story. Mayor Estella had spent a couple of days during the week in the provincial capital of Iba. After mass, Father Agustín, as usual, headed for the church door. The mayor was there waiting for him. The musical band was not there anymore. About twenty curious onlookers were observing the whole episode from a safe distance. The Recollect was still a few steps from the door when the mayor approached him. He hurled dagger looks at the Recollect priest and with indescribable gestures, told him he had not rendered due respect and honor to his authority. The minister had not sprinkled him with holy water during the Vidiaquam rite at the start of the mass. He could not help but smile at such an unexpected and ridiculous complaint. He then replied: "You would have complained just the same if you had been wet by the holy water." He turned furious and cut short the Recollect's reply. The mayor raised his cane and was about to hit the priest, but he restrained himself.

The priest asked to listen to his side, for even most notorious criminals were given a chance to speak. The mayor angrily shouted: "I do not permit you to speak. I give orders around here! We do not want friars here!" To this, the Recollect retorted: "So I go. Case closed." He headed for his residence with the mayor tailing behind. He 
passed by a group of American soldiers, to whom the mayor directed a question in a loud voice: "Don't you think there should be no friars here and this parish priest must leave this place?" The priest could not hear the answer from the Americans. These were the same soldiers who were disappointed with the parish priest who did not permit some scandalous women of ill repute to act as godmothers in baptism.

Father Agustín abandoned Masinloc three days later, on April 9. He firmed up his decision to head north and join other confreres in Infanta. He left at nine in the evening. No parishioner was around to sympathize with him. An American ship, fortunately, docked at Masinloc, and the captain agreed to board the Father Agustín without any fare. The ship was headed for Manila, and he needed to recover from his stomach ailment. He had been suffering lately from this stomach problem. He reached the capital two days later at 11 in the morning. He moved to San Sebastian convent later in the afternoon.

\section{The road to Palauig}

There was no decent road to Palauig to speak of before the Recollect missionary Father Marcial Bellido was installed as a parish priest in $1858 .^{34}$ Travel in the past was done by sea. This hardworking Recollect missionary was born in Tarazona, Aragón, Spain, on 21 May 1826. He pronounced the monastic vows in 1848. A year after he arrived in Manila in June 1852, Father Marcial was named companion or parochial vicar of Masinloc. He was sent to Iba as a parish curate in 1854-1855. After his triennial term as vice-prior and novice of the mother-house of Recoletos in Intramuros, Manila, he was elected as parish priest of Masinloc in 1858.

Father Marcial Bellido had been known to everyone in Masinloc as a hardworking man, endowed with an "unbreakable strength of character," and this he showed when he worked on the construction of the road that would connect Masinloc and the village of Palauig. The road project was deemed inconceivable. It was not considered doable at all. The terrain was horrifying to view. But with the help of the equally hardworking people of Masinloc and Palauig, the road was brought to its happy conclusion long before his parochial administration ended in 1870.

The thirty-four-year-old priest was elected superior of the Recollect formation house of Marcilla, Navarra in 1870. He was appointed prior of Monteagudo, Navarra. In this convent, Father Bellido rejoined his Maker on 27 October 1889.

Demography of Masinloc (1749-1897).

Our highly informative population statistics on the parish of Masinloc are culled from Labor evangélica de los padres agustinos recoletos en las Islas Filipinas, authored Father Fidel de Blas OAR and published by the Order in $1910:^{35}$

${ }^{34}$ SÁDABA, 456-457.

${ }^{35}$ Fidel DE BLAS, Labor evangélica de los padres recoletos en las Islas Filipinas (Zaragoza 1910) 16. 


\begin{tabular}{|l|c|c|c|c|c|l|}
\hline Year & Tributes & Souls & Baptisms & Weddings & Deaths & Parish Priest or Minister \\
\hline 1749 & 450 & 1552 & 58 & 16 & 31 & Fr. Mamés de San Lamberto \\
\hline 1770 & 596 & 2380 & 47 & 18 & 40 & Fr. Joaquín del Carmen \\
\hline 1778 & 646 & 3015 & 54 & 21 & 36 & Fr. Manuel de Jesús \\
\hline 1838 & $9541 / 2$ & 4766 & 208 & 74 & 198 & Fr. José Aranguren \\
\hline 1843 & 1042 & 5643 & 236 & 56 & 86 & Fr. Modesto Sesma \\
\hline 1847 & $11101 / 2$ & 5711 & 252 & 47 & 118 & The same \\
\hline 1851 & 873 & 4157 & 175 & 49 & 180 & Fr. Juan Engroba \\
\hline 1857 & 1058 & 4707 & 220 & 50 & 168 & Fr. Gregorio Bueno \\
\hline 1861 & 1099 & 4846 & 226 & 50 & 131 & Fr. MarcialBellido \\
\hline 1866 & 1191 & 5138 & 168 & 46 & 139 & The same \\
\hline 1871 & $12811 / 2$ & 5588 & 222 & 58 & 207 & Fr VictorianoVereciano \\
\hline 1877 & 1647 & 6541 & 297 & 50 & 122 & Fr. Agustín Pérez \\
\hline 1882 & $16791 / 2$ & 3805 & 205 & 68 & 114 & The same \\
\hline 1887 & 1377 & 5233 & 237 & 56 & 118 & The same \\
\hline 1891 & 3138 & 5586 & 138 & 26 & 231 & Fr. Vicente Pascual \\
\hline 1894 & 0786 & 2590 & 95 & 65 & 61 & Fr. Juan Ortiz \\
\hline 1897 & 3131 & 6855 & 203 & 26 & 85 & Fr. Agustín Pérez \\
\hline
\end{tabular}

\section{Coat-of-Arms of the Province of St. Nicholas of Tolentino ${ }^{36}$}

The missionary province of Saint Nicholas of Tolentino, which was established in 1621 by the papal decree Militantis Ecclesiae, is presently one of the four Augustinian Recollect provinces. It is the mother province of Saint Ezekiel Moreno Province, which was separated from it by the General Chapter on 28 November 1998. The coat-ofarms of Saint Nicholas Province are in the official seal, website, documents, books, and edifices. It is now in the restored metal pulpit of San Andrés church of Masinloc. The valuable history book Sinopsis histórica de la Provincia de San Nicolás de Tolentino de las Islas Filipinas, written by Licinio Ruiz OAR and published in Manila in 1925, displayed that same coat-of-arms on its inside front page.

In the exterior part of the coat-of-arms are the decorative carapace, the two arrows, a cardinal's hat with tassels, all taken from the coat-of-arms of the Order of Augustinian Recollects.

The basic design of the Recollect coat-of-arms consists of a heart afire and pierced by either one or two arrows. This represents their spiritual founder Saint Augustine's burning love for God and fellow men and women.

In the early part of the $20^{\text {th }}$ century, the entire Recollect Order gained renewal and new life from the Province of St. Nicholas and, on account of this, we find the patron Saint Nicholas represented by a lily at the base of the coat of arms which was adopted in 1921.

The four quarters inside are peculiar to Saint Nicholas of Tolentino Province:

The heart pierced by the arrow, and the book is both taken from the coat-of-arms of the Order of Augustinian Recollects. The Province of Saint

Nicholas of Tolentino belongs to the Order of Augustinian Recollects.

\footnotetext{
${ }^{36}$ Retrieved in 2006 from http://www.agustinosrecoletos.org/nosotros_quienes_en.php.
} 
The belt or cincture makes special reference to Saint Nicholas and his devotion to the Holy Souls of Purgatory, of whom he is now invoked as their patron saint.

The star, the most common symbol of Saint Nicholas whose images in countless churches and chapels in the Philippines contain this brilliant star on his chest, recalls a vision the saintly Augustinian priest had in which a star represented his own life and holiness.

The partridge on a platter is another popular symbol. It refers to a miracle performed by Saint Nicholas, who was well-known for his mortification and abstinence from meat. When he was presented with a roasted partridge by his religious superior, the holy priest ordered the bird to fly away. He had been caught in a dilemma: obedience to the superior or eating the roast partridge, thus breaking his vow of abstinence from meat.

\section{Conclusion}

To conclude, we quote the Recollect historian Father Licinio Ruiz on the faith of the people of Zambales:

What our Recollect religious achieved was not one of those ostentatious conquests wherein force played a primordial role, wherein the conqueror acquired domination-more or less superficial and ephemeral-over the vanquished. On the contrary, theirs was a work of faith, a work of Our Lord God. Thus, it is not strange that Christian faith is so intimate among the simple people of Zambales..."37

And this valuable legacy of Christian faith and culture lives on! Perhaps the most visible and most enduring of the legacies are the age-old edifices constructed in centuries past with the blood, sweat, and tears of both parish priests and ancestors of today's parishioners. And most important is the parish church of San Andrés, where definitely any person can be "enthralled by the sight and existence of the Spanish church" that has lasted through the years, overcoming merciless typhoons and tremors rising, not unlike the legendary Phoenix, from the rubble of earthquakes.

A Lutheran missionary, Don Fahrenbrink, once wrote about his deep feelings, as he beheld the grandiose and age-old divine temples that abound in our country:

These old churches fascinate me. When standing before them, especially in a remote place, I feel a sense of mystery that is hard to explain. Their enduring grandeur in spite of the centuries, the stories they could tell, the lives that touched their mortar and stone as part of faith; all this is certain magic for me. ${ }^{38}$

\footnotetext{
${ }^{37}$ RuIz, Sinopsisı, 23.

${ }^{38}$ Frances Engel, Don Fahrenbrink, The Philippine Datebook 1978, Manila 1978, 84.
} 
Truly the stone church of San Andrés was communal labor of love and solidarity. You have to cast that unfounded, fictitious concept of forced labor or slave labor into oblivion. The sturdy church of Masinloc is a visible landmark of the glory that once was Spain in the Philippines. Oh, if these stones could only speak.

This stone church of San Andrés is truly a silent witness to struggles and successes of the people of Masinloc who worked hard for the next generations to remember them as hardworking, generous, upright, God-fearing and God-loving people who against all odds constructed a temple, a house for the Lord that lasted all these decades and that would last for hundred years to come.

Indeed, it is a great feat of the human spirit! A great achievement of the People of God in Masinloc! A silent witness to the Augustinian Recollect missionary zeal!

\section{SOURCES AND BIBLIOGRAPHY}

\section{Unpublished Manuscript Sources}

Archivo Histórico de la Provincia de San Nicolás de Tolentino [AHPN] (Historical Archive of the Province of Saint Nicholas of Tolentino, Order of Augustinian Recollects), Marcilla, Navarre, Spain. Vicente PASCUAL.Breve reseña histórica de la fundación y vicisitudes por que ha pasado esta parroquia deMasinloc. Legajo 50b Folder 4, 7r-14r.

AHPN, Agustín PÉREz. Relación del viaje del que suscribe a Masinloc (Zambales) y delo acaecido durante mi permanencia de cuatro años en el mismo pueblo. Legajo 51, Folder 2, 16r-20r.

\section{Published Primary Sources}

ANDRÉS DEL ESPÍRITU SANTO, Relación de la fundación y progresos de esta santa Provincia de San Nicolás de Tolentino, in Boletín de la Provincia de San Nicolás de Tolentino de Filipinas [BPSN] 55 (1965) 66-179.

\section{Books}

Miguel Avellaneda. Continuación del Padre Sádaba, o segunda parte del 'Catálogo de los religiosos de la Orden de Agustinos Recoletos' (1906-1936). Rome 1938.

Peter DigalBALILI, JR. Life and Times of Mons. José Aranguren, OAR, Archbishop of Manila, 18541860. Quezon City 1993.

Leander BARROT [ed.] Recoletos: History, Legacy and Culture. Quezon City 2005.

ManuelCARCELler. Historia general de la Orden de Recoletos de San Agustín x. Madrid 1962. Historia general de la Orden de Agustinos Recoletos xI. Madrid 1967. . Historia general de la Orden de Agustinos RecoletosXII. Madrid 1971.

Fidel DE BLAS. Labor evangélica de los padres recoletos en las Islas Filipinas. Zaragoza 1910. 
Frances Engel, Don FAHREnBRINK.The Philippine Datebook 1978. Manila 1978.

Emilio P. JARUdA JR. [ed]. Commemorative Album of the 1988-1991 Triennium. Order of Augustinian Recollects, Vicariate of the Philippines, and China.Quezon City, 1991.

Patricio Marcellán. La Provincia de San Nicolás de Tolentino de los Agustinos Descalzos de la Congregación de España e Indias. Manila 1879.

Ángel Martínez CUeSTA. The Augustinian Recollects. Arrival in the Philippines and Spread of its Missionary Activities. Quezon City 2006.

. Historia de los Agustinos RecoletosII, Madrid 2015.

. Historia de los Agustinos Recoletosı, Madrid 1995.

. The Order of Augustinian Recollects. Its Charismatic Evolution, Manila 1994.

Emmanuel Luis A. Romanillos. The Augustinian Recollects in the Philippines: Hagiography and History. Quezon City, 2001.

Licinio Rulz. Sinopsis histórica de la Provincia de San Nicolás de Tolentino de las Islas Filipinas. 2 vols. Manila 1925.

Francisco SÁdABA. Catálogo de los Religiosos Agustinos Recoletos de la Provincia de San Nicolás de Tolentino de Filipinas desde el año 1606, en que llegó la primera misión a Manila, hasta nuestros días. Madrid 1906.

José Luis SÁENz Ruiz-Olalde.Los Agustinos Recoletos y la revolución hispano-filipina. Marcilla, Navarre, Spain 1998.

\section{Articles}

Bambi HARPER. The Recollects, in The Philippine Daily Inquirer, 3 April 2004.

Pedro HeRCE. The Recollects in the Philippines, in BoletínEclesiástico de Filipinas 435 (1965) 210-253.

Martín LegarRa. Los PP. Agustinos Recoletos en la Evangelización de Filipinas, in Misiones católicas en el Extremo Oriente, Manila 1937, 101-107.

Emmanuel Luis A. Romaniltos. Augustinian Recollect Icons, in The Recoletos Observer, April-June 2005, vol. 6, no. 2, pp. 2, 17-20; part II, in The Recoletos Observer, June-August 2005, vol. 6, no. 3, 21-24; part III, in The Recoletos Observer, September-December 2005, vol. 6 , no. $4,25-28$.

José Luis SÁENz RUIZ-OLALDE.Actividad pastoral, social y cultural de los agustinos recoletos en Filipinas, in Recollectio 16 (1993) 249-306.

. Invasiones de los moros filipinos en los ministerios agustinos recoletos a mediados del siglo XVIII: sus repercusiones en la vida social y religiosa de las misiones, in BPSN 75 (1985) 10-33. 